\title{
PENGARUH MODEL PEMBELAJARAN SEMINAR SOCRATES TERHADAP HASIL BELAJAR SISWA
}

\author{
I Wayan Redhana \\ FMIPA Universitas Pendidikan Ganesha Singaraja \\ email: redhana.undiksha@gmail.com
}

\begin{abstract}
Abstrak: Penelitian ini bertujuan untuk menyelidiki perbedaan hasil belajar antara siswa yang belajar dengan model pembelajaran seminar Socrates dan model pembelajaran langsung. Jenis dan rancangan penelitian berupa penelitian eksperimen semu dan nonequivalent pretest-posttest control group design. Populasi penelitian adalah siswa kelas XI IPA SMA Negeri 1 Gianyar, Bali, dengan sampel dua kelas XI IPA, yaitu XI IPA 3 dan XI IPA 4 yang masing-masing berjumlah 32 orang. Penentuan kelompok kontrol dan eksperimen dilakukan melalui pengundian. Data dikumpulkan dengan tes hasil belajar dan data dianalisis dengan statistik Ancova. Hasil penelitian menunjukkan bahwa terdapat perbedaan yang signifikan hasil belajar antara siswa yang belajar dengan model pembelajaran seminar Socrates dan siswa yang belajar dengan model pembelajaran langsung. Siswa yang belajar dengan model pembelajaran seminar Socrates menunjukkan hasil lebih tinggi daripada siswa yang belajar dengan model pembelajaran langsung.
\end{abstract}

Kata Kunci: seminar Socrates, pembelajaran langsung, hasil belajar

\section{THE EFFECT OF THE SOCRATIC SEMINAR LEARNING MODEL TOWARD STUDENTS' LEARNING ACHIEVEMENT}

\begin{abstract}
This study was aimed at investigating the difference of the learning achievement between students who learned using the Socratic seminar learning model and those who learned using the direct instructional model. This study belonged to the quasi-experiment using the nonequivalent pretest-posttest control group design. The population was all students of the XI Science program in SMAN 1 Gianyar, Bali. Two classes, that is, XI Science 3 and XI Science 4, were taken as the sample, each consisting of 32 students. The assignment of the groups was done through drawing a lot. The data were collected using a learning achievement test and analyzed using ANCOVA. The findings showed that there was a significant difference in the learning achievement of the students learning using the Socratic seminar learning model and those learning using the direct instructional model. The learning achievement of students who learned using the Socratic seminar learning model was higher than that of those who learned using the direct instructional model.
\end{abstract}

Keywords: socratic seminar, direct instruction, learning achievement

\section{PENDAHULUAN}

Tuntutan sumber daya manusia yang berkualitas sangat diharapkan di era globalisasi. Era globalisasi adalah suatu era yang mendorong terjadinya persaingan dalam segala aspek kehidupan, terutama bidang ekonomi, perdagangan, transportasi, dan telekomunikasi. Persaingan ini melahirkan pemenang dan pecundang. Negara yang memiliki sumber daya berkualitas dan mampu menguasai ilmu pengetahuan dan teknologi serta sejumlah keterampilan akan menjadi pemenang. Sebaliknya, negara yang tidak mampu menguasai ilmu pengetahuan dan teknologi serta sejumlah keterampilan akan menjadi pecundang. Oleh karena itu, penyiapan sumber daya manusia berkualitas tinggi sangat penting bagi suatu negara. 
Salah satu upaya yang dilakukan untuk menyiapkan sumber daya manusia berkualitas adalah melalui pendidikan. Pendidikan adalah usaha sadar yang dilakukan untuk menghasilkan lulusan yang berkompeten dan siap memasuki pasar bebas. Dalam upaya menyiapkan pendidikan berkualitas, Undang-Undang Nomor 20 Tahun 2003 tentang Sistem Pendidikan Nasional telah disahkan. Demikian juga Peraturan Pemerintah Republik Indonesia Nomor 19 Tahun 2005 tentang Standar Nasional Pendidikan telah ditetapkan. Dengan adanya standar ini, pemerintah berharap semua proses pendidikan yang belangsung harus mengacu kepada standar yang telah ditetapkan. Hal ini dilakukan untuk mengejar ketertinggalan dalam bidang pendidikan dari negera-negara maju dan negara-negara di Asia Tenggara lainnya.

Beberapa model pembelajaran inovatif telah dikembangkan oleh para ahli. Salah satu model pembelajaran untuk orang dewasa yang tersedia bagi guru adalah model pembelajaran seminar Socrates. Model pembelajaran ini diarahkan oleh guru menggunakan pertanyaanpertanyaan terbuka (Ulnanir \& Ultanir, 2010:9). Model pembelajaran ini menggunakan ide-ide Socrates. Socrates adalah sorang filosuf Yunani yang dikenal memiliki pemikiran kritis yang ideal.

Model pembelajaran seminar Socrates dapat dibagi menjadi tiga tahap, yaitu tahap sebelum seminar, tahap selama seminar, dan tahap setelah seminar. Kegiatan pada tahap sebelum seminar adalah: (1) penjelasan tujuan seminar Socrates untuk memfasilitasi siswa memahami pemahaman ide-ide dan nilai-nilai secara mendalam; (2) penugasan siswa untuk mempelajari teks yang telah disediakan; (3) penjelasan aturan pelaksanaan seminar Socrates; dan (4) memotivasi siswa untuk mengajukan pertanyaan dan memberikan komentar kepada siswa lain.

Kegiatan pada tahap selama seminar sebagai berikut. (1) Guru membagi kelas menjadi dua kelompok besar, yaitu kelompok dalam (kelompok diskusi) dan kelompk luar (kelompok observasi); siswa di kelompok dalam terlibat dalam kegiatan diskusi dan siswa di kelompok luar mendengarkan diskusi kelompok dalam.
(2) Siswa di kelompok luar mencatat dan menulis ide-ide atau komentar tentang apa yang mereka dengar selama diskusi berlangsung; setelah selesai satu topik, kedua kelompok berganti peran, yaitu kelompok dalam menjadi kelompok luar dan kelompok luar menjadi kelompok dalam. (3) Guru mengajukan pertanyaan pembuka untuk memulai diskusi.(4) Guru memfasilitasi diskusi dengan mengajukan klarifikasi, menyampaikan ringkasan komentar, serta menunjukkan dan memperbaiki kesalahan pemahaman siswa; guru dapat mengajukan kembali pernyataan pembuka jika diskusi keluar dari jalur. (5) Guru dapat mengajukan pertanyaan evaluatif untuk menilai suatu pendapat.

Kegiatan pada tahap setelah seminar adalah: (1) guru mengajukan pertanyaan "Apakah Anda sudah memahami materi yang didiskusikan?"; (2) guru menugaskan siswa berbagi pengalaman selama seminar; dan (3) guru menugasi siswa menulis satu atau dua paragraf tentang ide besar dari diskusi seminar Socrates (Northwest Association for Biomedical Research, 2012:167-169).

Penggunaan model pembelajaran seminar Socrates telah dilaporkan efektif sebagai pembelajaran aktif yang dapat meningkatkan hasil belajar dan keterampilan berpikir kritis siswa. Koellner-Clark, Stalling, dan Hoover (2002: 686) melaporkan bahwa model pembelajaran seminar Socrates sangat efektif memotivasi siswa dalam bernalar dan berkomunikasi. Siswa juga menunjukkan peningkatan pemahamannya terhadap materi yang dipelajari. Demikian juga, guru dapat menilai pemahaman konsep siswa. Selain itu, model pembelajaran seminar Socrates juga menyediakan diksusi yang kaya tentang topik yang dipelajari. Siswa mampu memecahkan masalah-masalah yang terdapat dalam buku-buku teks yang berhubungan dengan materi yang dipelajari. Model pembelajaran ini menyediakan kesempatan bagi siswa dan guru berpartisipasi dalam pembelajaran. Siswa memunyai forum untuk mengartikulasikan dan mengorganisasikan pemahaman, penalaran, dan keterampilan berkomunikasi, sementara guru dapat merefleksikan pemahaman siswa. Siswa yang berpartisipasi dalam model pembelajaran semi- 
nar Socrates menunjukkan pamahaman konsep yang lebih baik daripada siswa yang tidak berpartisipasi dalam model pembelajaran seminar Socrates.

Sementara itu, Conklin (2007:12) menyatakan bahwa seminar Socrates merupakan alat yang sangat baik untuk meningkatkan kemampuan berpikir siswa dan proses yang berlangsung adalah diskusi intelektual dalam basis konten yang dipelajari. Demikian juga, Paraskevas dan Wickens (2007:4) menyatakan bahwa seminar Socrates adalah bentuk pembelajaran yang diarahkan oleh guru. Pada seminar ini, pertanyaan digunakan sebagai metode pembelajaran yang utama. Seminar Socrates menempatkan siswa pada posisi mengenal keterbatasan pengetahuannya dan dapat memotivasi siswa untuk belajar. Seminar Socrates merupakan metode yang sangat efektif untuk mengajar siswa dewasa.

Tampaknya, terdapat beberapa kelemahan terhadap setting model pembelajaran seminar Socrates yang asli. Karena adanya pembagian kelompok dalam (diskusi) dan kelompok luar (observasi), serta kedua kelompok ini berganti peran. Proses pembelajaran memerlukan waktu yang lama, sementara waktu belajar di sekolah sangat terbatas untuk mencapai kompetensi yang ditetapkan dalam standar kompetensi dan kompetensi dasar. Oleh karena itu, perlu dilakukan beberapa modifikasi terhadap model pembelajaran seminar Socrates yang asli. Modifikasi yang dilakukan adalah sebagai berikut. Pertama, siswa dibagi menjadi beberapa kelompok. Setiap kelompok anggotanya terdiri atas 45 siswa. Semua kelompok tersebut berpartisipasi dalam kegiatan diskusi sehingga semua siswa memiliki kesempatan yang sama terlibat secara aktif dalam kegiatan diskusi. Dengan kata lain, tidak ada kelompok luar (observasi). Kedua, pelaksanaan seminar diawali oleh penyampaian ringkasan isi teks oleh salah satu kelompok. Penyampaian ringkasan ini bertujuan memokuskan pikiran siswa pada materi yang dipelajari.

Model pembelajaran seminar Socrates yang telah dimodifikasi ini selanjutnya diuji efektivitasnya dalam meningkatkan hasil belajar siswa. Dengan demikian, tujuan penelitian ini adalah mendeskripsikan efektivitas model pembelajaran seminar Socrates yang telah dimodifikasi untuk meningkatkan hasil belajar siswa. Untuk mengetahui efektivitas ini, model pembelajaran langsung digunakan sebagai pembanding. Alasan pemilihan model pembelajaran langsung sebagai pembanding karena kebanyakan guru kimia menggunakan model pembelajaran ini untuk mengajarkan materi pelajaran dengan alasan praktis, yaitu mudah dilakukan.

\section{METODE}

Untuk menguji efektivitas model pembelajaran seminar Socrates terhadap model pembelajaran langsung dalam meningkatkan hasil belajar kimia siswa, penelitian eksperimen kuasi dilakukan dengan rancangan penelitian berupa nonequivalent pretest-posttest control group design. Penelitian dilakukan pada topik gaya antarmolekul dan bentuk molekul. Pada penelitian ini, tes dilakukan sebanyak dua kali, yaitu sebelum perlakuan (pretes) dan setelah perlakuan (postes). Tes yang digunakan adalah tes yang sama, yaitu tes hasil belajar yang dikembangkan oleh peneliti. Tes hasil belajar ini berupa tes objektif dengan alasan yang berjumlah 30 item.

Populasi penelitian adalah siswa kelas XI SMAN 1 Gianyar Kabupaten Gianyar, Provinsi Bali yang terdiri atas delapan kelas. Sampel diambil dengan teknik kluster acak. Dengan teknik ini, sampel penelitian yang diperoleh adalah siswa kelas XI IPA 3 dan siswa kelas XI IPA yang masing-masing berjumlah 32 orang siswa. Dua kelas ini diundi untuk menentukan kelompok kontrol dan kelompok eksperimen.

Tahapan pembelajaran pada model pembelajaran langsung adalah sebagai berikut. Pertama, tahap orientasi, guru menginformasikan tujuan pembelajaran dan memotivasi siswa untuk belajar. Kedua, tahap presentasi, guru menyampaikan materi dan melakukan demonstrasi. Materi disajikan dalam langkah-langkah kecil sehingga materi dapat dikuasai oleh siswa dalam waktu relatif pendek. Ketiga, tahap latihan terstruktur, guru memandu siswa melakukan latihan-latihan dan memberikan umpan balik 
terhadap respon siswa. Jawaban siswa yang benar diberikan penguatan dan jawaban siswa yang kurang tepat diperbaiki. Keempat, tahap latihan terbimbing, guru memberikan kesempatan kepada siswa berlatih menerapkan konsep dan keterampilannya. Siswa diberi tugas mengerjakan soal-soal dengan cara berdiskusi. Guru memonitor dan memberikan bimbingan jika diperlukan. Kelima, tahap latihan mandiri, siswa diberi tugas yang dikerjakan secara mandiri. Tugas ini berupa pekerjaan rumah.

Tahapan pembelajaran pada model pembelajaran seminar Socrates sebagai berikut. Pertama, kegiatan tahap sebelum seminar adalah sebagai berikut. Guru menyampaikan tujuan pembelajaran dan memotivasi siswa belajar. Guru menyampaikan aturan seminar. Aturan seminar tersebut adalah: (1) ketika seorang guru atau siswa sedang berbicara, siswa lain tidak boleh melakukan interupsi; (2) semua siswa harus mendengarkan pendapat dari siswa lain dengan baik; (3) proses seminar harus berlangsung dalam suasana dialogis yang saling menghormati, bukan debat; (4) pendapat yang disampaikan harus didukung oleh bukti yang kuat, bukan didasarkan atas opini; dan (5) guru mengatur jalannya seminar agar berjalan dengan baik. Siswa dibagi menjadi kelompok-kelompok belajar yang anggotanya terdiri atas 4-5 orang. Selanjutnya, guru memberikan teks kepada seluruh siswa untuk dipelajari.

Kedua, kegiatan tahap selama seminar adalah sebagai berikut. Guru menugasi salah satu kelompok menyampaikan ringkasan materi teks. Kegiatan ini bertujuan memofuskan perhatian siswa. Guru sebagai pemimpin seminar mengajukan pertanyaan terbuka berkaitan dengan isi teks. Siswa dalam kelompok berdiskusi memikirkan jawaban terhadap pertanyaan guru. Guru menunjuk salah satu kelompok untuk menjawab pertanyaan. Kelompok lain juga diundang untuk memberikan tanggapan. Guru mengajukan pertanyaan selanjutnya berkaitan dengan materi dalam teks. Demikian seterusnya sampai seluruh siswa memahami materi dalam teks yang dipelajari.
Ketiga, kegiatan pada tahap setelah seminar adalah sebagai berikut. Guru dan siswa melakukan refleksi terhadap kegiatan pembelajaran yang telah berlangsung untuk mengetahui kendala-kendala/kesulitan-kesulitan yang dialami oleh siswa selama proses pembelajaran.

Untuk mendukung implementasi model pembelajaran langsung dan model pembelajaran seminar Socrates, perangkat pembelajaran berupa silabus dan rencana pelaksanaan pembelajaran (RPP) pada masing-masing model pembelajaran perlu dibuat. Silabus dan RRP dibuat pada topik gaya antarmolekul dan bentuk molekul. Sementara itu, untuk mengetahui hasil belajar siswa sebagai efek dari model pembelajaran yang diterapkan, tes hasil belajar pada topik gaya antarmolekul dan bentuk molekul dibuat. Tes ini berupa tes objektif dengan pemberian alasan. Namun, sebelum digunakan untuk mengukur hasil belajar siswa, tes ini terlebih dahulu divalidasi oleh dua orang ahli dan kemudian diuji keterbacaannya kepada lima orang siswa.

Data yang berupa skor pretes dan postes (hasil belajar) dianalisis secara deskriptif dengan menghitung skor rata-rata dan standar deviasi. Data skor pretes dan postes juga dianalisis dengan statistik parametrik berupa uji analysis of covariance (Ancova). Hipotesis yang diuji adalah sebagai berikut.

$\mathrm{H}_{\mathrm{a}}$ : Ada perbedaan yang signifikan hasil belajar antara siswa yang belajar dengan model pembelajaran seminar Socrates dan siswa yang belajar dengan model pembelajaran langsung.

$\mathrm{H}_{0}$ : Tidak ada perbedaan yang signifikan hasil belajar antara siswa yang belajar dengan model pembelajaran seminar Socrates dan siswa yang belajar dengan model pembelajaran langsung.

Sebelum uji Ancova dilakukan, uji prasyarat atau uji asumsi Ancova perlu dilakukan. Uji ini meliputi uji normalitas, uji homogenitas varians, uji linieritas, dan uji homogenitas kemiringan garis (uji interaksi). Semua uji ini dilakukan dengan bantuan software SPSS Ver.16 for Windows pada taraf signifikansi $5 \%$. 


\section{HASIL DAN PEMBAHASAN}

\section{Hasil Pretes dan Postes Siswa}

Analisis secara deskriptif terhadap skor pretes dan postes menghasilkan data deskriptif. Beberapa data deskriptif pretes dan postes dari hasil penelitian ini adalah skor rata-rata dan standar deviasi ditunjukkan pada Tabel 1.

Uji beda skor rata-rata postes antara kelompok kontrol dan kelompok eksperimen dengan pretes sebagai variabel kovariat dalam penelitian ini menggunakan statistik Ancova. Statistik Ancova merupakan perpaduan antara statistik Anova dan statistik regresi. Oleh karena itu, uji asumsi pada statistik Ancova juga merupakan perpaduan antara uji asumsi pada statistik Anova dan uji asumsi pada statistik regresi. Uji asumsi yang dimaksud meliputi uji normalitas, uji homogenitas varians, uji linieritas, dan uji homogenitas kemiringan garis regresi (uji interaksi). Hasil-hasil uji tersebut dapat diuraikan sebagai berikut.

\section{Uji Normalitas}

Uji normalitas adalah uji sebaran skor masing-masing pada skor pretes dan skor pos- tes, baik pada kelompok kontrol maupun pada kelompok eksperimen. Uji normalitas sebaran skor dilakukan dengan uji statistik Kolmogorov-Smirnov dan/atau Shapiro-Wilk. Hasil-hasil uji normalitas sebaran skor ditunjukkan dalam Tabel 2.

Semua nilai signifikasi yang diperoleh dari uji statistik Kolmogorov-Smirnov dan/atau Shapiro-Wilk (Tabel2) lebih dari 0,05 ( $>>0,05)$. Hal itu menglarifikasi bahwa sebaran skor pretes baik pada kelompok kontrol maupun pada kelompok eksperimen serta sebaran skor postes baik pada kelompok kontrol maupun pada kelompok eksperimen berdistribusi normal.

\section{Uji Homogenitas Varians}

Uji homogenitas varians dimaksudkan untuk mengetahui kehomogenan varians skor pretes antara kelompok kontrol dan kelompok eksperimen. Demikian juga, kehomogenan varians skor postes antara kompok kontrol dan kelompok eksperimen. Uji homogenitas varians ini menggunakan statistik Levene. Hasil uji homogenitas varians ditunjukkan dalam Tabel 3 .

Tabel 1. Deskripsi Skor Pretes dan Postes Siswa

\begin{tabular}{lcccc}
\hline \multirow{2}{*}{ Statistik } & \multicolumn{2}{c}{ Pretes } & Postes \\
\cline { 2 - 5 } & Kontrol & Eksperimen & Kontrol & Eksperimen \\
\hline Skor rata-rata & 28,0 & 29,1 & 56,4 & 66,3 \\
SD & 3,4 & 3,9 & 7,4 & 10,6 \\
\hline
\end{tabular}

Tabel 2. Hasil Uji Normalitas

\begin{tabular}{llllllll}
\hline \multirow{2}{*}{ Tes } & \multirow{2}{*}{ Model pembelajaran } & \multicolumn{3}{c}{ Kolmogorov-Smirnov } & \multicolumn{3}{c}{ Shapiro-Wilk } \\
\cline { 3 - 8 } & & Statistic & df & Sig. & Statistic & df & Sig. \\
\hline Pretes & langsung & 0,135 & 32 & 0,148 & 0,958 & 32 & 0,241 \\
& seminar Socrates & 0,129 & 32 & 0,192 & 0,968 & 32 & 0,454 \\
\multirow{2}{*}{ Postes } & langsung & 0,121 & 32 & 0,200 & 0,966 & 32 & 0,392 \\
& seminar Socrates & 0,107 & 32 & 0,200 & 0,958 & 32 & 0,247 \\
\hline
\end{tabular}


Tabel 3. Hasil Uji Homogenitas Varians

\begin{tabular}{llccrr}
\hline & & $\begin{array}{c}\text { Levene } \\
\text { Statistic }\end{array}$ & $\mathrm{df1}$ & $\mathrm{df} 2$ & \multicolumn{1}{c}{ Sig. } \\
\hline Pretes & Based on Mean & 0,374 & 1 & 62 & 0,543 \\
& 0,345 & 1 & 62 & 0,559 \\
& Based on Median & 0,345 & 1 & 60,766 & 0,559 \\
& Based on Median and with adjusted df & 0,376 & 1 & 62 & 0,542 \\
& Based on trimmed mean & 3,739 & 1 & 62 & 0,058 \\
Postes & Based on Mean & 2,858 & 1 & 62 & 0,096 \\
& Based on Median & 2,858 & 1 & 53,869 & 0,097 \\
& Based on Median and with adjusted df & 3,753 & 1 & 62 & 0,057 \\
Based on trimmed mean & & & & \\
\hline
\end{tabular}

Tabel 4. Hasil Uji Linieritas

\begin{tabular}{cclc}
\hline Kelompok & & Kriteria & Sig. \\
\hline \multirow{2}{*}{ Eksperimen } & \multirow{2}{*}{ Between group } & Linearity & 0,002 \\
& & Deviation from linearity & 0,175 \\
\multirow{2}{*}{ Kontrol } & \multirow{2}{*}{ Between group } & Linearity & 0,002 \\
& & Deviation from linearity & 0,439 \\
\hline
\end{tabular}

Angka signifikansi yang diperoleh lebih dari 0,05 ( $p>0,05)$ untuk semua kriteria homogenitas varians, baik pada skor pretes maupun skor postes. Hal itu menglarifikasi bahwa varians skor pretes antara kelompok kontrol dan kelompok eksperimen adalah homogen. Demikian juga, varians skor postes antara kelompok kontrol dan kelompok eksperimen adalah homogen.

\section{Uji Linieritas}

Uji linieritas merupakan merupakan uji asumsi yang diperlukan dalam uji regresi. Oleh karena uji regresi merupakan bagian dari uji Ancova, uji linieritas ini harus dipenuhi sebelum uji Ancova dilakukan. Uji linieritas merupakan uji untuk mengetahui adanya hubungan linier antara skor pretes dan skor postes baik pada kelompok kontrol maupun kelompok eksperimen. Hasil uji linieritas ditunjukkan dalam Tabel 4.

Angka signifikansi untuk deviation from linearity pada kelompok eksperimen sebesar 0,175 ( $>>0,05$ ). Hal itu menglarifikasi bahwa hubungan antara skor pretes (kovariat) dan skor postes (hasil belajar) adalah linier. Sementara itu, angka signifikansi untuk linearity pada ke- lompok eksperimen sebesar 0,002 $(\mathrm{p}<0,05)$. Hal itu menglarifikasi bahwa hubungan antara skor pretes (kovariat) dan skor postes (hasil belajar) berarti atau signifikan. Demikian juga, angka signifikansi untuk deviation from linearity pada kelompok kontrol sebesar 0,439 (p> 0,05 ). Hal itu menglarifikasi bahwa hubungan antara skor pretes (kovariat) dan skor postes (hasil belajar) adalah linier. Sementara itu, angka signifikansi untuk linearity pada kelompok kontrol sebesar 0,002 ( $p>0,05)$. Hal itu mengklarifikasi bahwa hubungan antara skor pretes (kovariat) dan skor postes (hasil belajar) berarti atau signifikan. Oleh karena itu, dapat disimpulkan bahwa hubungan antara skor pretes (kovariat) dan skor postes (hasil belajar), baik pada kelompok kontrol maupun eksperimen adalah linier dan berarti (signifikan).

\section{Uji Kemiringan Garis Regresi (Uji Interaksi)}

Uji kemiringan garis regresi atau uji interaksi dimaksudkan untuk mengetahui adanya tidaknya pengaruh model pembelajaran terhadap hasil belajar. Jika ada interaksi $(\mathrm{p}<0,05)$ antara garis regresi skor pretes dan skor postes pada kelompok kontrol dengan garis regresi antara skor pretes dan skor postes pada kelompok 
eksperimen, berarti hasil belajar siswa dipengaruhi oleh variabel lain, bukan oleh variabel model pembelajaran. Sebaliknya, jika tidak ada interaksi $(p>0,05)$ antara garis regresi skor pretes dan skor postes pada kelompok kontrol dengan garis regresi antara skor pretes dan skor postes pada kelompok eksperimen, hasil belajar siswa hanya dipengaruhi oleh variabel model pembelajaran, bukan oleh variabel yang lain. Hasil uji interaksi atau homogenitas kemiringan garis regresi ditunjukkan pada Tabel 5.

Angka signifikansi untuk baris Model* Pretest yang diperoleh dari uji interaksi adalah sebesar 0,778. Angka signifikansi ini lebih dari 0,05 sehingga dapat disimpulkan bahwa variabel kovariat tidak berpengaruh secara signifikan terhadap hasil belajar siswa. Dengan kata lain, variabel hasil belajar siswa hanya dipengaruhi oleh variabel model pembelajaran yang diterapkan.

\section{Uji Hipotesis}

Setelah semua uji asumsi dipenuhi, uji hipotesis dengan statistik Ancova dapat dilakukan. Hipotesis alternatif yang diuji adalah "Ada perbedaan yang signifikan hasil belajar antara siswa yang belajar dengan model pembelajaran seminar Socrates dan siswa yang belajar dengan model pembelajaran langsung." Untuk pengujian hipotesis alternatif ini, perlu dirumuskan hipotesis nol, yaitu "Tidak ada perbedaan yang signifikan hasil belajar antara siswa yang belajar dengan model pembelajaran seminar Socrates dan siswa yang belajar dengan model pembelajaran langsung." Pada pengujian ini, hipotesis nol ditolak jika angka signifikansi yang diperoleh kurang dari 0,05. Sebaliknya, hipotesis nol diterima jika angka signifikansi yang diperoleh lebih dari 0,05 . Hasil pengujian menggunakan statistik Ancova menghasilkan nilai signifikansi seperti ditunjukkan pada Tabel 6.

Tabel 5. Hasil Uji Homogenitas Kemiringan Garis Regresi

\begin{tabular}{lrrrrr}
\hline \multicolumn{1}{c}{ Source } & $\begin{array}{r}\text { Type III Sum of } \\
\text { Squares }\end{array}$ & df & Mean Square & F & Sig. \\
\hline Corrected Model & 2939,013 & 3 & 979,671 & 15,471 & 0,000 \\
Intercept & 588,117 & 1 & 588,117 & 9,287 & 0,003 \\
Model & 3,573 & 1 & 3,573 & 0,056 & 0,813 \\
Pretest & 1332,878 & 1 & 1332,878 & 21,048 & 0,000 \\
Model * Pretest & $\mathbf{5 , 0 5 9}$ & $\mathbf{1}$ & $\mathbf{5 , 0 5 9}$ & $\mathbf{0 , 0 8 0}$ & $\mathbf{0 , 7 7 8}$ \\
Error & 3799,494 & 60 & 63,325 & & \\
Total & 247733,590 & 64 & & & \\
Corrected Total & 6738,507 & 63 & & & \\
\hline
\end{tabular}

Tabel 6. Hasil Uji Hipotesis

\begin{tabular}{lrrrrr}
\hline \multicolumn{1}{c}{ Source } & $\begin{array}{c}\text { Type III Sum of } \\
\text { Squares }\end{array}$ & df & Mean Square & F & Sig. \\
\hline Corrected Model & 2933,954 & 2 & 1466,977 & 23,521 & 0,000 \\
Intercept & 583,255 & 1 & 583,255 & 9,352 & 0,003 \\
Pretest & 1378,638 & 1 & 1378,638 & 22,104 & 0,000 \\
Model & $\mathbf{1 0 8 5 , 4 7 6}$ & $\mathbf{1}$ & $\mathbf{1 0 8 5 , 4 7 6}$ & $\mathbf{1 7 , 4 0 4}$ & $\mathbf{0 , 0 0 0}$ \\
Error & 3804,553 & 61 & 62,370 & & \\
Total & 247733,590 & 64 & & & \\
Corrected Total & 6738,507 & 63 & & & \\
\hline
\end{tabular}


Angka signifikansi untuk baris Model yang diperoleh dari uji Ancova dengan bantuan software SPSS Ver.16 for Windows adalah 0,000 . Hal itu berarti hipotesis nol ditolak. Sebaliknya, hipotesis alternatif yang menyatakan "Ada perbedaan yang signifikan hasil belajar antara siswa yang belajar dengan model pembelajaran seminar Socrates dan siswa yang belajar dengan model pembelajaran langsung" diterima. Jika dicermati skor rata-rata postes siswa, tampak bahwa skor rata-rata postes kelompok eksperimen lebih tinggi daripada skor rata-rata postes kelompok kontrol. Dari skor rata-rata postes ini, simpulan yang dapat ditarik adalah model pembelajaran seminar Socrates lebih baik daripada model pembelajaran langsung dalam meningkatkan hasil belajar siswa.

\section{Pembahasan}

Berdasarkan hasil uji hipotesis yang telah dilakukan, simpulan yang dapat ditarik adalah ada perbedaan yang signifikan hasil belajar antara siswa yang belajar dengan model pembelajaran seminar Socrates dan siswa yang belajar dengan model pembelajaran langsung. Skor rata-rata hasil belajar siswa yang belajar dengan model pembelajaran Seminar Socrates $(66,3)$ lebih tinggi daripada skor rata-rata hasil belajar siswa yang belajar dengan model pembelajaran langsung $(56,4)$. Skor rata-rata pretes (variabel kovariat) kedua kelompok tidak berpengaruh terhadap hasil belajar siswa karena hasil uji interaksi mengklarifikasi bahwa tidak ada interaksi antara variabel kovariat dan variabel terikat. Hal ini menunjukkan bahwa perbedaan hasil belajar siswa semata-mata hanya disebabkan oleh perbedaan perlakuan yang diberikan atau model pembelajaran yang diterapkan. Dengan demikian, model pembelajaran seminar Socrates lebih baik daripada model pembelajaran langsung dalam meningkatkan hasil belajar kimia siswa.

Pada model pembelajaran seminar Socrates, guru menyediakan teks atau ulasan materi yang berkaitan dengan topik yang dipelajari. Penyediaan teks atau ulasan materi ini dimaksudkan untuk menyediakan bahan atau materi. Siswa juga diminta mempelajari materi yang dari sumber-sumber lain. Dengan demikian, siswa akan memiliki pemahaman yang kaya terhadap materi yang akan didiskusikan pada saat pelaksanaan seminar Socrates. Pelaksanaan seminar Socrates diawali oleh penyajian materi atau ulasan oleh salah satu kelompok siswa. Penyajian ini untuk memofukan perhatian siswa terhadap materi yang dipelajari. Dengan cara ini, siswa berusaha mengingat semua materi yang telah dipelajari. Kemudian, guru mengajukan pertanyaan terbuka kepada kelompok siswa. Pertanyaan terbuka ini merupakan inti dari seminar Socrates.

Paraskevas dan Wickens (2007:6) menyatakan bahwa seminar Socrates melibatkan pengunaan pertanyaan sistematik, berpikir induktif, dan formulasi definisi umum. Siswa dipresentasikan dengan skenario dan guru mengajukan sederetan pertanyaan secara sistematik. Pertanyaan dirancang untuk membimbing siswa mengkonstruksi pengetahuannya. Siswa perlu menggunakan pengalaman dan pengetahuan yang mereka miliki untuk memecahkan masalah sederhana dan kompleks atau isu-isu yang diajukan melalui pertanyaan. Berikutnya, teknik induktif digunakan untuk membantu siswa mempelajari materi secara lebih luas. Sekali ide generik dan konsep dipahami, guru menggunakan pertanyaan untuk membantu siswa mengembangkan rasional atau definisi yang lebih universal dari suatu konsep. Dengan cara ini, siswa mempunyai kesempatan untuk menunjukkan pemahaman yang komprehensif terhadap materi yang dipelajari.

Dengan pertanyaan terbuka, siswa ditantang untuk berusaha menemukan jawaban dari pertanyaan tersebut. Selain itu, siswa juga berusaha untuk menghasilkan jawaban dari pertanyaan dan/atau mengajukan pertanyaan kepada siswa lain. Dengan demikian, proses pembelajaran berlangsung dalam dialog yang saling menghargai di antara siswa. Berkaitan dengan dialog ini, King (2011:7) menyatakan bahwa seminar Socrates menekankan pada pertanyaan guru, dialog, dan produksi pengetahuan sendiri. Dalam usaha menjawab pertanyaan terbuka ini, siswa berusaha menerapkan dan mengembangkan keterampilan berpikir tingkat tinggi, 
khususnya keterampilan berpikir kritis dan keterampilan berpikir kreatif.

Keterampilan berpikir tingkat tinggi ini merupakan tiga level atas dalam taksonomi Bloom, yaitu analisis, sintesis, dan evaluasi. Untuk mencapai keterampilan berpikir tingkat tinggi, guru harus melakukan reformasi pembelajaran, yaitu melakukan pergeseran dari pengajaran tradisional (keterampilan berpikir tingkat rendah) ke pembelajaran yang menekankan pada keterampilan berpikir tingkat tinggi (Lubezky, Dori, \& Zoller, 2004:175). Item-item keterampilan berpikir tingkat tinggi adalah pertanyaan, latihan, atau masalah-masalah ill-defined/ill-structured, yaitu pertanyaan, latihan, atau masalah yang baru bagi siswa dan memerlukan solusi lebih dari sekadar aplikasi pengetahuan. Solusi memerlukan analisis, sintesis, berpikir sistem, pembuatan keputusan, keterampilan pemecahan masalah, pembuatan hubungan, dan berpikir evaluatif kritis. Item-item keterampilan berpikir tingkat tinggi ini meliputi aplikasi teori atau pengetahuan pada situasi yang tidak mirip. Dengan keterampilan berpikir tingkat tinggi, siswa mampu mengindarkan diri dari penipuan, indokrinasi, dan pencucian otak (brainwashing) (Lipman, 2003:209).

Pengembangan keterampilan berpikir tinggi ini sangat penting dilakukan dalam proses pembelajaran karena keterampilan berpikir tingkat tinggi merupakan jantung dari masa depan semua masyarakat di seluruh dunia (Zoller, Ben-Chaim, \& Ron, 2000:572). Candy (1991: 328) melaporkan bahwa keterampilan berpikir tingkat tinggi merupakan salah satu tujuan yang paling penting dari semua sektor pendidikan. Oleh karena pembelajaran merupakan alat untuk menyiapkan siswa menjadi anggota masyarakat agar dapat hidup bertanggung jawab dan aktif dalam masyarakat berbasis teknologi, sekolah pada semua tingkatan seharusnya memokuskan pada pengembangan keterampilan berpikir tingkat tinggi siswa .

Dengan demikian, tujuan utama dari pembelajaran adalah untuk mengembangkan keterampilan berpikir tingkat tinggi (keterampilan berpikir kritis) dari siswa dalam konten dan proses sains (Zoller, Ben-Chaim, \& Ron,
2000:572). Elam (McTighe \& Schollenberger, 1985:3) menyatakan bahwa keterampilan berpikir tingkat tinggi merupakan tujuan pendidikan tertinggi. Ernst dan Monroe (2004:509) menyatakan bahwa tujuan perbaikan keterampilan berpikir tingkat tinggi adalah untuk menciptakan penduduk yang literasi terhadap lingkungan (environmental literacy).

Pengembangan keterampilan berpikir tingkat tinggi selama pembelajaran dapat mendorong terjadinya peningkatan terhadap hasil belajar siswa. Hal ini disebabkan oleh hasil belajar merupakan ranah dari taksonomi Bloom. Keterampilan berpikir tingkat tinggi yang merupakan tiga level atas (analisis, sintesis, dan evaluasi) dalam taksonomi Bloom didasari oleh tiga level di bawahnya (ingatan, pemahaman, dan aplikasi). Dengan kata lain, peningkatan hasil belajar siswa terjadi karena siswa memperoleh pengalaman menjawab pertanyaan yang menuntut penerapan dari keterampilan berpikri tingkat tinggi.

Hasil-hasil penelitian tentang pengembangan keterampilan berpikir tingkat tinggi khususnya keterampilan berpikir kritis, melalui penerapan model pembelajaran seminar Socrates telah dilaporkan oleh beberapa ahli. Conklin (2007:12) menyatakan bahwa seminar Socrates merupakan alat yang sangat baik untuk meningkatkan kemampuan berpikir siswa. Dalam seminar Socrates, proses yang berlangsung adalah diskusi intelektual. Picciano (2009:12) menyatakan bahwa seminar Socrates merupakan model pembelajaran utama yang digunakan dalam pembelajaran. Masih menurut Picciano, guru-guru sangat senang karena pertanyaan yang mereka ajukan dapat membantu siswa mengembangkan keterampilan berpikir kritis siswa.

Sementara itu, Tucker dan Neely (2010: 15) menyatakan bahwa seminar Socrates dapat membantu guru memotivasi siswa dalam dialog yang menantang siswa berpartisipasi dalam pembelajaran aktif. Tujuan seminar Socrates adalah memotivasi siswa menjadi seorang pemikir kritis dan pemecah masalah. Seminar Socrates ini menekankan pada belajar aktif dalam usaha untuk menciptakan pengalaman belajar 
yang bermakna. Di lain pihak, Luther (2006:72) menyatakan bahwa seminar Socrates mampu mengembangkan kesadaran kritis siswa karena mereka dikonfrontasikan dengan kontradiksi ekonomi, politik, dan sosial. Alfonsi (2008:69) mengungkapkan pernyataan siswa berkaitan dengan implementasi seminar Socrates: “....I could never understand people when I was closed in and not open with others about my ideas. Now that I have learned to share, my mind has opened a new doorway for my life."

Selain pengembangan aspek kognitif dan keterampilan, model pembelajaran seminar Socrates juga mampu mengembangkan kerja tim, tanggung jawab belajar, serta menciptakan lingkungan belajar sosial yang positif. Hal ini dimungkinkan karena model pembelajaran seminar Socrates mengembangkan belajar kooperatif. Pada diskusi kelompok ini terjadi pengajaran teman sejawat (peer tutoring). Siswa yang kemampuan akademiknya baik mengajari siswa yang kemampuan akademiknya kurang. Demikian juga terjadi pertukaran ide-ide di antara siswa. Dengan demikian, proses ini menghasilkan jawaban atau solusi terbaik terhadap pertanyaan atau masalah yang diajukan oleh guru. Melalui proses kooperatif ini, juga dapat mengembangkan keterampilan berpikir kritis siswa.

Hal senada juga diungkapkan oleh Mandal (2009:98) yaitu bahwa pembelajaran kooperatif dapat mengembangkan keterampilan berpikir tingkat tinggi, menciptakan lingkungan belajar yang aktif, memperbaiki kinerja siswa yang kemampuan akademiknya kurang, dan mentolerasi gaya belajar yang berbeda di antara siswa. Sementara itu, Akhtar, dkk. (2012:144) menyatakan bahwa dalam pembelajaran kooperatif, setiap anggota kelompok memunyai komitmen dan tanggung jawab yang tinggi untuk keberhasilan kelompok. Selain itu, pembelajaran kooperatif dapat meningkatkan kemampuan siswa bersosialisasi dengan siswa yang lain dan mereka dapat menyelesaikan tugas-tugas dengan baik dan belajar lebih baik daripada jika mereka belajar secara individu.

Dalam model pembelajaran seminar Socrates tidak terjadi persaingan antarkelompok.
Hal ini disebabkan proses pembelajaran seminar Socrates diatur oleh beberapa prinsip, seperti:(1) siswa tidak boleh melakukan interupsi ketika siswa lain sedang berbicara; (2) semua peserta mendengarkan dengan baik apa yang disampaikan oleh siswa lain; (3) pendapat harus didasarkan atas bukti yang kuat; dan (4) proses diskusi harus dalam suasana dialogis, bukan debat.

Sementara itu, model pembelajaran langsung yang diterapkan pada kelompok kontrol belum mampu mengoptimalkan peran siswa secara aktif. Meskipun siswa sudah diberi tugas mempelajari materi sebelum pembelajaran dimulai, tetapi hal tersebut tidak menjamin bahwa siswa benar-benar telah belajar. Jika siswa hanya diberi tugas mempelajari materi di buku dengan membaca tanpa ada pertanyaan yang memacu siswa berpikir, maka kemungkinan siswa hanya membaca tanpa berusaha memahami materi secara lebih mendalam. Pada fase presentasi, guru menjelaskan dan memberi contoh kepada siswa. Pada proses ini, siswa hanya menerima penjelasan guru dan kesempatan siswa menemukan dan membangun pemahamannya sendiri sangat kurang. Materi yang dijelaskan oleh guru hanya menjadi bahan hafalan sehingga pemahaman siswa masih kurang. Pada fase latihan terbimbing, siswa cenderung lebih banyak menerapkan cara-cara atau prosedur-prosedur yang didasarkan atas hafalan, bukan pemahaman. Siswa sangat sulit menerapkan konsep jika siswa menghadapi situasi masalah yang berbeda dari yang dicontohkan oleh guru.

Pada pelaksanaan model pembelajaran seminar Socrates terdapat beberapa kendala. Kendala-kendala tersebut sebagai berikut. Pertama, pengaturan ruangan pada kelompok eksperimen memerlukan cukup banyak waktu. Pengaturan ruangan menjadi bentuk lingkaran dan mengubah kembali menjadi letak semula membutuhkan waktu yang lama sehingga dapat mengganggu waktu pelajaran lain. Hal ini dapat diatasi dengan memanfaatkan ruangan laboratorium kimia yang cukup luas dan posisi tempat duduk dapat diatur oleh peneliti sebelum dan sesudah pelaksanaan pembelajaran kimia. Pada saat pelajaran kimia, siswa berpindah ruangan 
belajar ke laboratorium kimia. Jarak antara ruangan kelas dan laboratorium tidak terlalu jauh sehingga waktu yang diperlukan untuk berpindah tidak lama. Jadi, kondisi ini tidak mengganggu kegiatan pembelajaran. Kedua, kesulitan siswa menyesuaikan diri dengan model pembelajaran seminar Socrates. Pada model pembelajaran ini, siswa membutuhkan waktu untuk menyesuaikan diri. Pada pertemuan-pertemuan awal, guru masih perlu memberikan banyak arahan kepada siswa agar seminar tidak terhenti. Namun, pada pertemuan-pertemuan selanjutnya siswa sudah aktif berdiskusi dengan siswa lain.

\section{PENUTUP}

Berdasarkan hasil-hasil yang diperoleh dalam penelitian ini, dapat disimpulkan bahwa terdapat perbedaan hasil belajar antara siswa yang belajar dengan model pembelajaran seminar Socrates dan siswa yang belajar dengan model pembelajaran langsung. Hasil belajar siswa pada model pembelajaran seminar Socrates lebih baik daripada hasil belajar siswa pada model pembelajaran langsung. Hal ini menunjukkan bahwa penerapan model pembelajaran seminar Socrates berpengaruh terhadap hasil belajar siswa. Dengan demikian, model pembelajaran seminar Socrates efektif meningkatkan hasil belajar siswa.

Berdasarkan hasil-hasil yang telah dicapai, saran-saran yang dapat diajukan sebagai berikut. Pertama, pada penerapan model pembelajaran seminar Socrates, guru harus mengatur tempat duduk siswa menjadi posisi lingkaran agar pembelajaran berlangsung lebih efektif. Kedua, model pembelajaran seminar Socrates dapat dijadikan model pembelajaran alternatif oleh guru-guru untuk meningkatkan hasil belajar siswa. Ketiga, penggunaan model pembelajaran seminar Socrates perlu diterapkan pada materi pelajaran kimia yang lain sehingga dapat diketahui keajegan dari pengaruh model pembelajaran berbasis seminar Socrates terhadap hasil belajar siswa.

\section{UCAPAN TERIMA KASIH}

Ucapan terima kasih disampaikan kepada pihak sponsor yang telah mendanai penelitian ini. Selain itu, ucapan terima kasih juga disampaikan kepada Ni Wayan Vera Listiana yang ikut membantu pelaksanaan penelitian ini.

\section{DAFTAR PUSTAKA}

Akhtar, K., Perveen, Q., Kiran, S., Rashid, M., \& Satti, A. K. 2012. "A Study of Student's Attitudes towards Cooperative Learning." International Journal of Humanities and Social Science, 2(11), hlm. 141-147.

Alfonsi, C. 2008. "Hey, Teacher! Get off the Stages: Assessing Student Thingking with Socratic Seminar." Ohio Journal of English Language Arts, 48(1), hlm. 65-71.

Candy, P. 1991. Self-Direction for Lifelong Learning. San Francisco: Jossey Bass.

Conklin, H. G. 2007. "Methods and The Middle: Elementary Preservice Teachers' View in Their Preparation for Teaching Middle School Social Studies." Research in Middle Level Education, 31(4), hlm. 116.

Ernst, J. \& Monroe, M. 2004. "The Effects of Environment-Based Education on Students' Critical Thinking Skills and Disposition Toward Critical Thinking." Environmental Education Research, 10(4), hlm. 507-522.

King, A. 2011. "Culture, Learning, and Development: A Case Study in the Ethiopian Higher Education System." http://www.kcl.ac.uk/study/learningteaching/kli/ research/hern/hern-j4/Andrew-King-hernjvol4.pdf. Diunduh 12 September 2012.

Koellner-Clark, K., Stallings, L. L., \& Hoover, S. A. 2002. "Seminar Socratic for Mathematics." Mathmatic Teacher, 95(9), hlm. 682-687. 
Lipman, M. 2003. Thinking in Education. $2^{\text {nd }}$ Ed. Cambridge: Cambridge University Press.

Lubezky, A., Dori, Y. J., \& Zoller, U. 2004. "HOCS-Promoting Assessment of Students' Performance on Environment-Related Undergraduate Chemistry." Chemistry Education Research and Practice, 5(2), hal. 175-184.

Luther, J. 2006. "I-Searching in Context: Thinking Critically about the Research Unit." English Journal, 95(4), hlm. 68-74.

Mandal, R. R. 2009. "Cooperative Learning Strategies To Enhance Writing Skill." The Modern Journal of Applied Linguistics, 1, hlm. 94-102.

McTighe, J. \& Schollenberger, J. 1985. "Why Teach Thinking? A Statement of Rational," dalam A. L. Costa (Eds). Developing Mind: A Resource Book for Teaching Thinking (hlm. 3-6). Alexandria: Association for Supervision and Curriculum Development.

Northwest Association for Biomedical Research 2012. "Evaluating Genetic Tests: A Socratic Seminar Discussion." http://nwabr.org/sites/default/files/Genetic_Tes ting_Lesson6_NWABR.pdf. Diunduh 27 Juni 2012.

Paraskevas, A. \& Wickens, E. 2007. “Andragogy and the Socratic Method: the Adult Learner Perspective." Journal of Hospitality, Leisure, Sport \& Tourism Education, 2(2), hlm. 4-14.
Peraturan Menteri Pendidikan Nasional Republik Indonesia Nomor 41 Tahun 2007 tentang Standar Proses untuk Satuan Pendidikan Dasar dan Menengah.

Peraturan Pemerintah Republik Indonesia Nomor 19 Tahun 2005 tentang Standar Nasional Pendidikan.

Picciano, A. G. 2009. "Blending with Purpose: The Multimodal Model." Journal of the Research Center for Educational Technology, 5(1), hlm. 4-14.

Tucker, J. P. \& Neely, P. W. 2010. "Using Web Conferencing and the Socratic Method to Facilitate Distance Learning." International Journal of Instructional Technology and Distance Learning, 7(6), hlm. 15-22.

Ultanir, Y. D. \& Ultamir, E. 2010. "Exploring the Curriculum Dimensions of TheoriesBased Adult Education, a Sample Course of Southeast Anatolian Region." International Journal of Instruction, 3(2), hlm. 3-24.

Undang-Undang Republik Indonesia Nomor 20 Tahun 2003 tentang Sistem Pendidikan Nasional.

Zoller, U., Ben-Chaim, D., \& Ron, S. 2000. "The Disposition toward Critical Thinking of High School and University Science Students: An Inter-Intra-IsreaeliItalian Study." International Journal of Science Education. 22(6), hlm. 571-582. 